\title{
KURIKULUM PENDIDIKAN ISLAM MASA KLASIK
}

\author{
Laelatul Badriah \\ Prodi PGMI STIA Alma Ata Yogyakarta \\ Email: laelatulbadriah0205@gmail.com
}

\begin{abstract}
Curriculum is a term that is very important for a good education lembaga Islamic educational institutions and public educational institutions. The curriculum covers all aspects related to the learning process. But studies curriculum more focus on four components, namely subject, goals, methods, and learning outcomes. Classical Islamic education curriculum can be regarded an Islamic education system beginning still very simple but of simplicity that is capable of scoring leaders, scholars, scientists lauar very unusual. Education applied Rosulullab in his time, he is the forerunner of Islamic education process that is capable of inspiration friends, Tabin, tabi'in tabi'in at this time. Education Rosulullab then forwarded by the first four Rasyidbani government period, then passed back to the Umayyads and the 'Abbasids Bani period. Where in each of the reign of Muslims is generally the same that emphasizes learning ketaubidan or divinity in order to establish the people Islam earlier. However curriculum that has not been well documented it can be inferred consists of learning materials, teaching methods, the subject of learning, learning outcomes and competence.
\end{abstract}

Keywords: curriculum, classical period, education.

\section{PENDAHULUAN}

Hampir setiap orang sudah sangat akrab dengan istilah kurikulum pendidikan Islam, namun apakah yang terkait dengan istilah kurikulum pendidikan itu sendiri. Oleh karena itu sebelum membahas lebih jauh kurikulum pendidikan Islam akan lebih baik jika ketahui terlebih dahulu arti bahasanya. Kurikulum berasal dari bahasa latin yaitu currere yang berati lapangan perlombaan. Kurikulum adalah suatu program pendidikan yang berisikan berbagai bahan ajar dan pengalaman belajar yang diprogramkan, direncanakan, dan dirancang secara sistematik atas dasar norma-norma yang berlaku yang dijadikan pedoman dalam proses pembelajaran bagi tenaga kependidikan dan 
peserta didik untuk mencapai tujuan pendidikan ${ }^{1}$. Berdasarkan pengertian ini, dalam konteknya dengan dunia pendidikan, memberi pengertian kurikulum sebagai konten pembelajaran yang muncul dalam proses pembelajaran yang mengakibatkan terjadinya interaksi pembelajaran untuk mencapai tujuan pembelajaran dalam bahasa yang singkat bisa dikatakan kurikulum sebagai materi pembelajaran.

Dalam Bahasa Arab, kurikulum dikenal dengan kata Manbaj yang berati jalan yang terang atau jalan yang dilalui manusia pada berbagai bidang kehidupannya. Jika dikaitkan dengan pendidikan maka Manhaj adalah jalan terang yang dilalui pendidik dengan yang dididik untuk mengembangkan pengetahuan, keterampilan, dan sikap ${ }^{2}$. Kurikulum berasal dari bahasa latin yaitu currere yang berati lapangan perlombaan. Kurikulum adalah suatu program pendidikan yang berisikan berbagai bahan ajar dan pengalaman belajar yang diprogramkan, direncanakan, dan dirancang secara sistematik atas dasar norma-norma yang berlaku yang dijadikan pedoman dalam proses pembelajaran bagi tenaga kependidikan dan peserta didik untuk mencapai tujuan pendidikan ${ }^{3}$. Berdasarkan pengertian di atas dapat disimpulkan bahwa kurikulum merupakan isi bahan ajar yang akan di sampaikan kepada peserta didik beserta metode penilaian pembelajaran yang dapat mengantarkan peserta didik untuk mencapai tujuan bembelajaran yang telah direncanakan sesuai dengan program pembelajaran.

Pendidikan Islam adalah pendidikan yang falsafah dasar dan tujuan serta teori-teori yang dibangun untuk melaksanakan praktik pendidikan didasarkan nilai-nilai dasar Islam yang terkandung dalam Al-Qur'an dan Hadits Nabi SAW. Dari beberapa pengetian di atas dapat disimpulkan kurikulum pendidikan Islam merupakan serangkaian komponen pembelajaran yang digerakkan untuk mencapai tujuan pembelajaran berdasarkan perencanaan dan sistem pembelajaran yang telah ditentukan untuk mecapai tujuan pembelajaran yang sempurna berdasarkan pada nilai-nilai dasar Islam yang terkandung dalam Al-Qur'an dan Hadits.

Kemajuan dalam bidang ilmu pengetahuan dan kebudayaan menyebabkan luasnya cakupan kajian kurikulum pendidikan. Oleh karena itu para ahli kurikulum membatasi cakupan kurikulum pendidikan menjadi empat bagian

${ }^{1}$ Dakir, perencanaan dan pengembangan Kurikulum, cet.1 (Rineka Cipta , jakarta: 2004), hlm. 2-3

${ }^{2}$ Arifudin Arif, Pengan Ilmu Pendidikan Islam cet. 1, (Kultura GP Press Group, Jakarta: 2008), hlm. 79-80

${ }^{3}$ Dakir, perencanaan dan pengembangan Kurikulum, cet.1 (Rineka Cipta , jakarta: 2004), hlm. 2-3 
saja yaitu pertama bagian yang berkenaan dengan tujuan yang akan dicapai, kedua bagaian yang berisi ilmu pengetahuan yang menjadi kajian yang akan disampikan kepada peserta didik (materi/subjek pembelajaran), ketigabagian yang berisi metode atau cara pembelajaran, keempat bagian yang berisi metode atau cara melakukan hasil belajar kompetensi akhir ${ }^{4}$. Pembahasan kurikulum pendidikan Islam sangat luas sekali oleh karena itu, pembahasan dalam makalah ini dibatasi hanya pada kurikulum pendidikan Islam pada masa klasik ( masa Rosulullah, masa Kholifah Al Rosyidi, masa Bani Umayyah, masa Bani Abbasiyah).

\section{Kurikulum Pendidikan Islam Masa Rosulullah SAW}

Mengidentifikasi kurikulum pendidikan yang diajarkan oleh Rosulullah terasa sangat sulit karena beliau mengajar pada lembaga kehidupan manusia yang belum ada ketentuan yang baku. Beliau mengajarkan umatnya dimana pun beliau berada baik ditempat keramaian orang maupun ditempat yang sepi seperti di rumah, di masjid, di jalan, di pasar dan lain sebagainya. Pendidikan masa Rosulullah terbagi menjadi dua periode yaitu periode Mekkah sebelum Nabi pergi berhijrah di madinah dan periode Madinah setelah Nabi pergi berhijrah di Madinah.

\section{Periode di Mekkah (611-622M)}

Secara umum tujuan Pendidikan di Mekkah berlangsung sebelum Nabi berhijrah ke Madinah, pendidikan yang berlangsung di Mekkah dapat diketahui melalui visi, misi, tujuan sasaran, kurikulum, metode, pendekatan dalam pembelajaran, sarana prasarana, dan evaluasi. Adapun tujuan pendidikan di Mekkah adalah membentuk tujuan manusia yang beriman dan bertakwa, dan berakhlak mulia sebagai landasan bagi mereka dalam menjalani kehidupan sosial. Adapun tujuan pendidikan secara khusus adalah bertujuan agar manusia dapat bertingkah laku mulia dan menjauhi tingkah laku jahat ${ }^{5}$. Tujuan ini didasarkan pada konteks keadaan sosial masyarakat Mekkah yang ketika itu masih dalam proses awal keIslaman dan masyarakat yang masih dikenal dengan tradisi jahiliyahnya.

Sentral pendidikan Rosulullah pada periode Mekkah ini ada tiga hal yaitu Aqidah (Keimanan), Akhlak ${ }^{6}$ dan Al-Qur'an ${ }^{7}$. Aqidah (keimanan), materi

\footnotetext{
${ }^{4}$ Abudin Nata Filsafat Pendidikan Islam 1 (Logos, Jakarta, 1997) h;lm,125

${ }^{5}$ Ahmad Tafsir, Cakrawala Pemikran Pendidikan Islam, (Bandung, Mimbar Pustaka: 2004), hlm. 255

${ }^{6}$ Haidar Putra Daulay dan Nurgaya Pasa, Penididkan Islam Dlam Lintasan Sjarab Kajian dari zaman pertumbuhan sampai kebangkitan, (Kencana Predana Media Group, Jakarta:2013) hlm. 22-23

${ }^{7}$ Zuhairini, dkk, Sejarah Pendidikan Islam cet. II (Jakarta, PTAIN IAIN Jakarta, 1985)
} 
yang diajarkan menitik beratkan pada masalah teolog dan ibadah yang meliputi iman kepada Allah, iman kepada Rosul-Nya dan iman kepada hari akhir, serta amal ibadah yaitu shalat. Akhlak, menurut Mahmud Yunus materi pendidikan akhlak ini bertujuan agar manusia agar bertingkah laku mulia dan menjahui tingkah laku jahat. ${ }^{8} \mathrm{Al}$-Qur'an, adalah inti sari dan sumber pokok dari ajaran Islam yang disampaikan oleh Nabi Muhammad SAW kepada Ummatnya. Tjuaun Nabi mengajarkan Al-Qur'an kepada umatnya adalah agar secara utuh dan sempurna menjadi milik umatnya yang selanjutnya akan menjadi warisan ajaran secara turun temurun, dan menjadi pegangan dan pedoman hidup bagi kaum muslimin sepanjang zaman. Adapun ayat-ayat Al-Qur'an yang diajarkan Nabi kepada umat Islam pada masa Mekkah hanya berkisar pada ayat-ayat Al-Qur'an yang berjumlah 93 surat $^{9}$ Zuharini menyebutkan selian tiga materi diatas pada periode Mekkah juga sudah mulai diajarkan ilmu akliyah dan ilmu Ilmiyah, serta pendidikan kesehatan. ${ }^{10}$

Pendidikan Islam pada masa Rosullullah periode Mekkah ini sanagat menekankan pada aspek aqidah, dimana saat itu masyarakat Mekkah sangat membutuhkan penanaman dan penggemblengan mental dan moral untuk meneguhkan keimanan kepada agama Islam dengan meng-Esa-kan Allah (monitehisme) dimana saat itu masyarakat Mekkah masih menganut politheisme. Rosulullah ketika itu sangat berupaya mengembleng dan menanamkan keyakinan dalam hati umat Islam dengan sekuat-kuatnya dari tantangan, rintangan, dan hamabatan dari kaum kafir Quraisy yang sangat hebat. Dengan penanaman tauhid yang kokoh ini berhasil mengantarkan umat Islam dari ancaman dan bahaya kaum kafir Quraisy.

Ada beberapa faktor yang memungkinkan Nabi mengajarkan Al-Qur'an dengan baik dan sempurna yaitu diantaranya masyarakat bangsa Arab pada saat itu masih dikenal masyarakat yang ummi yang pada umumnya tidak dapat membaca dan menulis, dan tradisi budaya mereka adalah tradisi budaya lisan, warisan budaya mereka juga diwariskan secara lisan. Dengan tradisi lisan ini mereka dikenal sebagai orang-orang yang kuat hafalan. ${ }^{11}$ Tradisi lisan yang dimiliki oleh para sahabat ini sangat dimanfaatkan secara optimal oleh Rosullullah untuk menghafal ayat-ayat Al-Qur'an yang turun secra berangsur-

hlm. 27

${ }^{8}$ Ahmad Tafsir, dkk, Cakrawala Pendidikan Islam, (Bandung, Mimbar Pustaka: 2004), hlm. 255

${ }^{9}$ Suarat suarat tang diturunkan sebelum nabi berhijrah ke madinah yang kemudian dinamakan dengan surat makkiyah

${ }^{10}$ Zuhairii, dkk, Sejarah Pendidikan Islam, (Bumi Aksara, jakarta, 2004), blm. 27

${ }^{11} \mathrm{Ibid}$, hlm. 28 
angsur. Bagi para sahabat yang memiliki kemampuan menulis Rosulullah memeritahakan untuk menuliskan ayat-ayat Al-Qur'an. Para sahabat menuliskan Al-Qur'an di dedaunan, pelepah kurma, kulit binatang dan lainnya. Rosullulah secra langsung menjadi contoh penerapan ketauhidan dalam kehidupan seharihari. Hasilnya kebiasaan masyarakat arab jika memulai sesuatu dengan nama berhala diganti dengan mengucapkan Bismillabirrohmannirrobim, kebiasaan menyembah berhala diganti dengan menyembah dan mengagungkan Allah SWT.

Kata-kata Aqidah, Akhlak, dan Al-Qur'an pada masa itu belum menjadi nama mata pelajaran atau bidang studi. Adapun sains pada waktu itu belum juga menjadi materi pelajaran akan tetapi Nabi hanya memberikan dorongan kepada kaumnya untuk memperhatikan kejadian manusia, hewan, tumbuhan dan alam raya. ${ }^{12} \mathrm{Hal}$ ini dilakukan Rosulullah dikarenakan pada periode ini beliau berada pada masa-masa perjuangan yang sangat hebat untuk menanamkan tauhid yang kuat di dalam hati umat Islam sehingga tidak ada penamaan mata pelajaran pada saat itu. Menurut Syamsul Nizar materi pendidikan Islam periode Mekkah ini terbagi menjadi dua yaitu materi pendidikan tauhid, dan materi pengajaran Al-Qur'an ${ }^{13}$, dimana materi tauhid tersebut lebih difokuskan pada memurnikan ajaran agama tauhid yang dibawa Nabi Ibrahim yang telah diselewengkan oleh masyarakat jahiliah. Sedangkan pada materi Al-Qur'an di bagi menjadi tiga yaitu pertama, materi baca tulis Al-Qur'an yang diharapkan dapat merubah kebiasaan masyarakat arab yang sering membaca syair-syair indah diganti dengan kebiasaan membaca Al-Qur'an yang indah yang lebih tinggi nilai sastranya, kedua, mengahafal ayat-ayat suci Al-Qur'an, ketiga, materi pemahaman Al-Qur'an yang berfungsi meluruskan pola fikir umat Islam yang dipengaruhi oleh pola fikir jahilliah.

Metode pembelajaran yang dilakukan oleh Rosulullah masih sangat sederhana, secara garis besar pada periode Mekkah yaitu dengan melalui dua tahap. Metode pembelajaran yang digunakan Nabi ketika di Mekkah untuk megajar para sahabat dan kaum muslim pada waktu itu dengan cara sembunyi-sembunyi selain itu juga Nabi menggunakan metode pidato dan ceramah ditempat-tempat yang ramai di kunjungi orang. ${ }^{14}$ Metode pembelajaran yang dilkukan Rosulullah pada periode Mekkah menyesuaikan materi apa yang diajarkan secara garis besar ketika Nabi menyampaikan materi Aqidah

${ }^{12}$ Ahmad Tafsir, dkk, Cakrawala Pendidikan, hlm 225

${ }^{13}$ Syamsul Nizar, Sejarah Pendidikan Islam Menelusuri jejak Sejarah pendidikan Era Rosulullab samapai Indonesia cet. 5, ( jakarta, Kencaa perdana , 2013), hlm. 34

${ }^{14}$ Suwendi, Sejarah dan Pemikiran Islam, (Jakarta, Raja grafindo Persada: 2004) hlm. 7 
Nabi lebih sering menggunakan metode pembiasaan yang dilakukan dalam kehidupan sehari-hari tentunya dalam hal ini dipraktikkan dalam menjalankan kehidupanya disesuaikan dengan ajaran Islam. Pada materi Akhlak Nabi lebih sering menggunakan metode keteladan dalam meyampaikan materi pembelajarannya.Keteladan yang dilakukan Nabi juga sama halnya seperti mengajarkan Aqidah yang dikaitkan dalam praktik menjalankan kehidupan sesuai dengan ajaran Islam. Dan pada materi Al-Qur'an Nabi menggunakan metode hafalan sebagaimana dialami oleh beliau sendiri ketika beliau menerima wahyu yang pertama dengan cara menghafal sampai tiga kali.

Menurut Samsul Nizar metode pembelajaran yang dilakukan Rosulullah dalam membidik para sahabat pada periode Mekkah yaitu ceramah, dialog, pembiasaan, keteladanan, kisah, dan hafalan. ${ }^{15}$. metode ceamah, menyampaikan wahyu yang baru turun dan memberikan penjelasannya, metode dialog seperti dialog Rosulullah ketika mengatur strategi perang, metode hafalan, mengahafal ayat ayat $\mathrm{Al}$-Qur'an, metode kisah, seperti kisah beliau ketika Isra' dan Mi'raj, dan metode pembiasaan, seperti pembiasaan kaum muslimin untuk shalat berjama'ah.

Menurut penulis metode pembelajaran yang digunakan Rosulullah pada periode Mekkah ini suatu metode yang sangat halus supaya bisa masuk dalam hati para sahabat yang notabene pada waktu itu masih masa-masa yang penuh tantang, godaan, ancaman, dan siksaan bagi umat Islam dari kaum kafir Quraisy sehingga beliau memilih metode metode pembelajaran yang semudah mungin bisa diterima oleh umat Islam pada waktu itu tentunya dengan menyesuaikan kondisi, situasi, kejadian, dan peristiwa yang dialami umat Islam saat itu.

Hasil belajar merupakan sesuatu hal yang diharapkan dari hasil proses belajar peserta didik. Pada masa sekarang ini hasil belajar merupakan sesuatu yang sangat dinantikan oleh para orang tua untuk melihat hasil belajar anaknya. Selanjutnya, Nabi pada periode ini khusus untuk mata pelajaran Al-Qur'an untuk memantapkan bacaan Al-Qur'an para sahabat Nabi mengadakan ulangan untuk mengecek bacaan dan hafalan Al-Qur'an para sahabat dengan cara membaca dan menghafal didepan Nabi dan Nabi membenarkan jika bacaannya terdapat kekeliruan. ${ }^{16}$ Dengan demikian hasil untuk mengetahui hasil belajar para sahabat nabi secara langsung mengevaluasi atau mengulang kembali hafalan Al-Qur'an para sahabat dihadapan Rosulullah.

Hasil belajar pada periode Mekkah ini adalah dengan melihat hasil belajarnya yang diimplementasikan dalam kehidupan yang beragama sesuai

\footnotetext{
${ }^{15}$ Syamsul Nizar, Sejarab Pendidikan Islam Menelusuri jejak Sejarab pendidikan Era........
} blm. 35

${ }^{16}$ Zuhairii, dkk, Sejarah Pendidikan Islam, (Bumi Aksara, jakarta, 2004), blm. 30 
dengan ajaran Islam. Pendekatan yang dilakukan oleh Rosulullah adalah dengan pendekatan pribadi pada tahap ini yang berhasil memeluk Islam adalah Khadijah, Ali bin Abi Thalib, Zaid bin Haritsah, Abu Bakar, Usman bin Affan, Zubair bin Awwam, Sa'ad bin Abi Waqos, Thalhah bin Ubaidilah, Abu Ubaidah bin Jarrah Arqom bin Arqom ${ }^{17}$. Bisa dikatakan bahwa para tokoh inilah yang dapat dikatakan sebagai hasil belajar pada pendidikan di periode Mekkah. Dengan menggunakan metode dan pendekatan pembelajaran yang menyesuikan kondisi dan situasi serta tidak membuat sedih akan tetapi menyenangkan para sahabat Rosulullah berhasil mencetak kader kader pemimpin yang tangguh kuat, yang memiliki komitmen bagi perjuangan Islam dan kepribadian yang kokoh dan mulia. Dimana mereka itulah sebagai model yang ideal bagi penerus umat Islam. Selanjutnya, Rosulullah menggambarkan para muridnya seperti binatang yang menerangi dan menunjukkan jalan. Yang kemudian mereka itulah generasi pertama (al sabiquna al awwalun) yang sebagian mereka dijamin masuk surga. ${ }^{18}$

Berbicara lembaga pendidikan Islam pada peroiode Mekkah, pada saat itu masih sangat sederhana sekali tepat pertama yang digunakan Rosulullah untuk proses pembelajaran para sahabat yaitu di rumah tepat di rumah sahabat Arqom yang kemudian dikenal dengan Dar al Arqom ${ }^{19}$ sebagai lembaga pendidikan Islam pertama. Materi yang diajarkan pada dar al Arqom ini adalah pokok-pokok ajaran Islam dan hukum-hukum. Selain dar al Arqom ada juga lembaga yang disebut Kuttab ${ }^{20}$, pendidikan di kuttab ini berbeda dengan Dar al Arqom, materi yang diajarakan di Kuttab lebih terfokus pada baca, tulis, dan syair arab. Akan tetapi setelah Islam datang diganti dengan baca tulis Al-Qur'an.

\section{Periode di Madinah (611-622M / 1-11 H)}

Ketika Rosulullah hijrah ke Mdinah pertama kali dilakukan oleh Rosulullah adalam membangun masjid di Madinah, di masjid itulah Rosulullah menjalankan proses pendidikan akan tetapi tidak menutup kemungkinan nabi menjalankan pendidikan di luar masjid Madinah. Pendidikan pada Periode Madinah yang secara langsung diajarkan Rosulullah kepada umat Islam pada masa itu. Sistem pendidikan pada periode Madinah ini secara umum adalah melanjutkan sistem pendidikan yang dilakukan pada periode Mekkah akan

${ }^{17}$ Haidar Putra Daulay dan Nurgaya Pasa, Penididkan Islam Dlam Lintasan Sjarab Kajian dari zaman pertumbuban sampai kebangkitan, (Kencana Predana Media Group, Jakarta:2013) blm. 22-23

${ }^{18}$ Abuddin Nata, Seajarab Pendidikan Isalm, (Kencana Predana Media Group, Jakarta: 2013), blm. 87

${ }^{19}$ Syamsul Nizar, Sejarah Pendidikan Islam Menelusuri, ....hlm. 36

${ }^{20} \mathrm{Ibid}$, hlm. 36 
tetapi ada ciri khusus dari tujuan pendidikannya yaitu pembinaan pendidikan sosial dan politkagar dijiwai dengan tauhid, sehingga akhirnya tingkah laku sosial politiknya merupakan cermin dan pantulan sinar tauhid yang berdasarkan wahyu yang diturunkan kepada $\mathrm{Nabi}^{21}$

Pendidikan pada masa ini sudah mulia komplek dengan keadaan masyarakat yang didominasi golongan Anshor sebagai penduduk asli kota Madinah dan golongan Muhajirin sebagai pendatang umat Islam dari Mekkah. Secara umum materi pendidikan periode Madinah berkisar pada empat bidang yaitu pendidikan keimanan, pendidikan akhlak, kesehatan jasmani dan pengetahuan yang berkaiatan dengan kemasyarakatan. ${ }^{22}$ Pendidikan terdiri keimanan sebagai tujuan utama tujuan Islam dan pendidikan Islam untuk mencapai keridhoan Allah yang paling penting adalah meng-Esakan Allah. Pendidikan akhlak lebih menekankan pada penguatan basis mental yang dilakukan pada periode Mekkah, pendidikan akhlak sebagai penekanan mencetak generasi muda yang bermoral dan berakhlakul karimah sesuai dengan ajaran Islam dan sebagai suri tauladannya secara langsung dimodelkan oleh Rosulullah. Pendidikan kesehatan jasmani lebih ditekankan pada penerapan nilai-nilai amaliah dari ibadah. Materi ini dianggap penting oleh nabi sebagai pemaknaan amaliah dari ibadah yang dapat memberi manfaat bagi kesehatan jasmani, seperti makna wudlu, shalat, puasa, dan haji. Sedangkan pendidikan yang berkait dengan kemasyarakatan meliputi bidang sosial, politik, ekonomi, dan hukum. Seperti tentang berkehidupan berumah tangga, warisan, hukum perdata dan pidana, perdagangan, dan kenegaraan serta lain-lainnya.

Metode yang dikembangkan Rosulullah dalam bidang keimanan adalah tanya jawab dengan perasaan yang halus dan didukung bukti-bukti yang rasional dan ilmiah. Metode pendidikan yang digunakan pada materi ibadah biasanya meliau menggunakan metode peneladanan. Sedangkan pada pendidikan akhlak metode yang digunakan dengan cara membacakan ayat-ayat Al-Qur'an yang berisi kisah-kisah umat terdahulu yang dimaknakan dalam kehidupan dengan menekankan pada metode peneledanan. ${ }^{23}$ pembelajaran yang digunkan dalam masa Madinah juga sudah mulai komplek tentunya metode yang digunakan juga semakin berkembang menyesuaikan suasana masyarakat Madinah pada saat itu. Metode yang digunakan nabi dan para sahabat yang ditunjuk nabi pada saat itu tentunya tidak lepas dari metode pidato dan ceramah. Dengan melihat materi dan beberapa metode yang digunakan Nabi pada periode

\footnotetext{
${ }^{21}$ Zuhairii, dkk, Sejarab Pendidikan Islam. blm. 33

${ }^{22}$ Ahmad Tafsir, dkk, Cakrawala Pendidikan, hlm. 225

${ }^{23}$ Ibid., hlm. 10
} 
Mekkah maka menurut penulis paling tidak ada bebrapa metode yang digunakan dalam penerapan pendidikan di Madinah yaitu ceramah, pidato, tanya jawab, musyawarah, hafalan, keteladanan, bimbingan, cerita, bermain peran. Metode metode ini diseusuaikan dengan konsisi dan situasi peserta didik. Mengutip pendapat Abuddin Nata menyesuaikan dengan fitrah manusia, maka pembelajaran dengan menggunakan pendekatan fitrah, yakni memberikan pelajaran sesuai dengan tingkat kemampauan, intelektual, kecerdasan, latar belakang, situasi, dan kondisi peserta didik saat itu. ${ }^{24}$

Mengidentifikasi pencapaian hasil belajar pada periode Madinah terasa sangat sulit karena pada masa itu banyak terjadi peristiwa yang di alami kaum muslim akan tetapi tidak dapat terdokumentasikan secara baik. secara umum dapat disimpulkan bahwa pendidikan Islam pada masa ini juga masih sama seperti periode Mekkah yaitu Rosulullah berhasil mencetak kader kader pemimpin yang tangguh kuat, yang memiliki komitmen bagi perjuangan Islam dan kepribadian yang kokoh dan mulia. Dimana mereka itulah sebagai model yang ideal bagi penerus umat Islam. Selanjutnya, Rosulullah menggambarkan para muridnya seperti binatang yang menerangi dan menunjukkan jalan. Selain itu juga, dengan titik ukur keberhasilan sosial politik masyarakat Madinah yang mampu membawa kaum muslim menuju kesejahteraan masyarakat dan peluasan wilayah kekuasaan Islam dengan sinar ketauhidan yang kuat.

Lembaga pendidikan di Madinah terdapat beberapa yaitu masjid, Al Suffah, Kuttab ${ }^{25}$. Setelah berhijrah ke Madinah pusat pendidikan pindah ke masjid-masjid, sebagai masjid pertama adalah masjid Quba. Didalam masjid inilah Rosulullah melakukan proses pembelajaran dan memberi khotbah dalam bentuk halaqoh untuk mendengarkan dan tanya jawab berkaitan dengan agama dan kehidupan sehari ini. Berdasarkan catatan sejarah semakin luas wilayah kekuasaan Islam semakin banyak pula masjid masjid-masjid yang dibangun. Diantara masjid yang dijadikan pusat penyebaran ilmu dan pengetahuan ialah masjid Nabawi, Masjid Haram, Masjid, Kufah, Masjid, Bashrah, dan lainnya.

Selain masjid terdapat pula istilah lembaga al Suffah dimana alsuffab ini merupakan suatu bangunan yang bersambung dengan masjid yang digunakan untuk prosespembelajaran secara rutin dan sistematik. Al Suffah ini juga dijadikan sebagai asrama bagi mereka yang belum memiliki tempat tinggal yang kemudian dinamakan $A b l$ al Suffah. Lembaga pendidikan selanjutnya adalah Kuttab, di Kuttab inilah Rosulullah pernah memerintahkan kepada tawanan

\footnotetext{
${ }^{24}$ Abuddin Nata, Seajarah Pendidikan Isalm blm. 97

${ }^{25}$ Abudin Nata, Sejarab Pendidikan Islam hlm.98-99
} 
perang Badar untuk mengajarkan baca tulis pada 10 anak-anak umat Islam sebagai syarat membebaskan diri dari tawanan. Dengan cara inilah lembaga kuttab yang awalnya tidak mendapatkan perhatian dari bangsa arab kemudian di manfaatkan Rosulullah sebagai tempat proses pembelajaran.

\section{Kurikulum Pendidikan Islam Masa Khulafa Al Rasyidin (632-661M / 12-41H)}

Sistem pendidikan Islam pada masa Khulafah al Rosyidin dilakukan secara mandiri tidak dikelola oleh pemerintah kecuali pada masa khalifah Umar bin Khatab. Pusat Pendidikan pada masa ini tidak hanya di Mekkah saja karena sadah menyebar di berbagai daerah kota Arab. Pendidikan pada masa ini secara umum bertujuan melahirkan umat yang tulus dan kukuh terhadap pelaksanaan ajaran Islam sebagaimana yang dijarkan oleh Nabi Muhammad SAW. ${ }^{26}$ Akan tetapi dari setiap kholifah memiliki tujuan pendidikan Islam masing- masing, seperti pada masa Abu Bakar:

Memantapkan ajaran Islam dilkalangan bangsa arab terutama bagi mereka yang murtad dan yang tidak mau membayar zakat.

Memberikan pendidikan agama bagi mereka yang beru memeluk agama Islam.

Memberikan pembelajaran Al-Qur'an

Memberikan pendidikan agama baik yang baru maupun yang sudah lama masuk Islam.

Mengajarkan agam Islam ke wilayah plosok pada masa itu. ${ }^{27}$

Pada masa Umar bin Khatab, sistem pendidikan yang berlaku sudah mulai dibentuk jenjang tingkat pendidikan dengan materi yang berbedabeda. Materi yang diajarkan pada masa ini berkisar masalah alQur'an, akidah ibadah, syariah dan akhlak. Selain itu juga ada pelajaran berenang, menungggang kuda, pepatah-pepatah dan syair-syair yang baik. Pada jenjang pendidikan Pendidikan dasar materi yang diajarkan: membaca, menulis dan mengahafal al qur'an, serta dasar-dasar agama, seperti wudlu, shalat, puasa dan lain laian. Menurut Mahmud Yunus Selain itu juga diajarkan berenang menunggang kuda, syair-syair baik, dan lain sebagainya. ${ }^{28}$ Sedangkan menurut Ahmad Shalaby mereka juga diajarkan tata bahasa arab, cerita

\footnotetext{
${ }^{26}$ Ibid.hlm. 119.
}

${ }^{27}$ Haidar Putra aulay dan Nurgaya Pasa Pendidikan Islam dalam Lintas Sejarab kajian dari zaman pertumbuban samapai kebangkitan, (kencana Media Group, Jakarta: 2013) hlm.52

${ }^{28} \mathrm{Ibid}$, hlm 53 
nabi-nabi, terutama hadits-hadits Rosulullah. Pendidikan ini dilaksanakan di kuttab.Pendidikan menengah dan pendidikan tinggi dilaksanakan di masjidmasjid dengan materi Al-Qur'an dan tafsirnya, hadits dan pengumpulanya, dan fiqih (tasyri' $)^{29}$.

Materi pendidikan pada masa Usman bin Affan berisi materi pendidikan agama, pendidikan aqidah, ibadah, akhlak, dan alQur'an. Pendidkan dilkukan samahalnya pada masa Umar bin Khotob. Sedangkan materi pada masa kholifah Ali berpusat pada materi agama meliputi akidah, ibadah, akhlak, al qur;an, mu'amalah, jinayah, hudud, dan masalah-masalah hukum Islam lainnya, tujuan pembelajaranya adalah membentuk kepribadian muslim yang berakhlakul karimah. Adapun matode pembelajaran yang digunakan dalam proses pembelajaran secara umum dengan menggunakan metode sorogan dan metode halaqoh yang dipadukan dengan metode ceramah dan hafalan. Sedangkan kegiatan evalusi masih berlangsung secara lisan dan praktik perbuatan. Bahwa kemampuan seseorang dalam menguasai bahan ajar dilihat dari kemampuannya untuk mengemukakan, mengajarkan, dan mengamalkan ajaran tersebut. ${ }^{30}$

Lembaga pendidikan sebagai penyelenggara pendidikan Islam periode Khalifaur Rasyidin menurut Syalabi yang dikutip Mahmud Yunus adalah masjid dan kuttab. Masjid dijadikan sebagai benteng pertahanan rohani, tempat pertemuan, lembaga pendidikan Islam, tempat shalat berjama'ah, tepat musyawarah, tempat membaca Al-Qur'an, sedangkan Kuttab lembaga yang digunakan untuk belajar membaca dan menulis. Berdasarkan uraian diatas dapat disimpulkan bahawa lembaga pendidikan masjid untuk orang dewasa atau untuk pemahaman ilmu pengetahuan, dan lembaga kuttab untuk anakanak yang beru belajar membaca dan menulis atau lembaga pendidikan dasar.

\section{Kurikulum Masa Bani Umayyah (41-132H/661-750M)}

Masyarakat muslim pada masa ini tumbuh menjadi masyarakat yang multikultural, beragam etnis, dan berbagai bangsa telah menjadi pemeluk agama Islam. Maka terbentuklah masyarakat yang pluralis yang semakin membutuhkan pendidikan. Ditinjau dari segi pendidikan yang berlangsung pada masa Umayyah terdapat dua lembaga pendidikan yaitu masjid dan kutab dimana kedua fungsi lembaga ini masih sama halnya pada masih Kholifah al Rosyidin.

Hasan Langgulung menyebutkan bahwa jasa besar Bani Umayyah adalah perkembangan ilmu pengetahuan yang berpusat di masjid sebagai

\footnotetext{
${ }^{29}$ Ibid hlm. 54

${ }^{30}$ Abudin Nata, Sejarab Pendidikan Islam.........hlm. 124
} 
perkembangan aktifitas ilmiah, termasuk syair, sejarah bangsa-bangsa terdahulu, perdebatan dan akidah. Adapun tujuan pendidikan pada masa Umayyah ini adalah secara umum Abudin Nata menyebutkan menghasilkan sumberdaya manusia yang unggul secara seimbang dalam ilmu agama dan ilmu umum searta mampu menerapkan bagi kemajuan wilayah Islam. ${ }^{31}$ Selanjutnya Philip K Hitti menyebutkan pada masa bani Umayyah terjadi kewalaupun majuan dalam bidang pendidikan walaupun sejarah mencatat pada masa ini tidak ada lembaga pendidikan formal..$^{32}$, Kemajuan dalam bidang pendidikan dengan tanpa adanya lembaga pendidikan formal dapat mengantarkan pada kemajuan pendidikan seperti dalam bidang ilmu Pengetahuan, ilmu pengobatan ala Nabi walaupun dikritik oleh Ibnu Kaldun dalam bukunya Muqoddimab bahwa Nabi Itu di utus untuk mengajarkan Islam bukan untuk mengajarkan pengobatan, selan itu juga dalam bidang Arsitektur, seni musik dan seni rupa gerakan penerjemah ilmu pengetahuan dari yunani ke dalam bahasa arab.

Materi pendidikan yang diajarkan pada masa ini berjalan secara alamiah yang kemudian muncul dinamika yang menjadi karakteristik pendidikan Islam ketika itu yaitu dibukanya wacana kalam yang brekembang di tengah masyarakat. Samsul Nizar diantara ilmu ilmu yang dikembangakan pada masa umayyah yaitu kedokteran, filsafat, astronomi, ilmu pasti, sastra, seni baik seni bangunan, seni musik, seni rupa, maupun seni suara. ${ }^{33}$

Kondisi ketika itu diwarnai dengan kepentingan politik dan golongan, terutama dunia sastra sangat rentan dengan identitas masing-masing. Pada masa ini pula muncul gerakan penerjemah ilmu-ilmu pengetahuan seperti ilmu kedokteran, kimia, falak, tata laksana dan seni bangunan yang didasari oleh kepentingan sendiri tanpa ada dukung dari negara. Selain ilmu- ilmu tersebut diatas pada masa ini masih melanggengkan tradisi ilmu terdahulu yang hampir tenggelam pada masa sebelumnya seperti ilmu tafsir. Pada masa ini juga mulai dikembangkan ilmu nahwu, dan mulai digerakkan untuk menulis dan mengumpulkan hadits-hadits Nabi.

Pada masa Umar bin Abdul 'Aziz telah melahirkan metode pendidikan alternatif yaitu para ulama mencari dan menuliskan kembali hadist kepada orang-orang yang dianggap mengetahuinya. Metode ini dikenal dengan metode riblah. Selain hadits juga diajarkan hukum fiqih, secara garis besar hukum fiqh dibagi menjadi dua kelompok yaitu aliran Ablal-Ra'ydan ablal hadits ${ }^{34}$.

${ }^{31}$ Ibid, hlm. 132 hlm. 316

${ }^{32}$ Pilip K Hitty , History Of the Arabs. Terj. (Jakarta, Serambi Ilmu Semesta, 2014),

${ }^{33}$ Samsul Nizar, Sejarah Pendidikan Islam .hlm. 60

${ }^{34}$ Mahmud Yunus Sejarah pendidikan Islam (Hida karya Agung, jakarta: 1990 M) 
Selanjutnya dapat disimupulkan materi pendidikan yang diajarkan pada masa ini meliputi ilmu ilmu agama, ilmu sejarah dan geografi, ilmu filsafat, dan ilmu pengetahuan bidang bahasa. Selain itu dalam poses pendidikan nilai nilai utama ditekankan pada masa umayyahmeliputi keberanian, kesabaran, toleransi denngan tetangga, muru'ah, kedermawanan, keramah tamahan, pengormatan kepada perempuan, dan menempati janji.

Adapun lembga pendidikan pada Masa Bani Umayyah diantarnaya adalah, masjid, kutab, pendidikan istanah, badiah, perpustakaan, al bimaristan (rumah sakit). Pendidikan istana mengajarkan ilmu agama, dan ilmu pegetahuan umum. selain itu sejarah mencatat pendidikan istanah ini tidak hanya pada pendidikan dasar saja akan tetapi sampai pada pendidikan tingggi sebagaimana munculnya istilah balaqoh, masjid, dan madrasah. Materi yang diajarkan meliputi al qur'an, hadits, syair-syair, riwayat hukama, menulis, membaca, dan lain sebainya. Sedangkan badiah merupakan tempat untuk belajar bahasa arab.

Metode yang digunakan adalah sorogan atau mandiri bagi pendidikan menengah dan halaqoh bagi bagi pendidikan tingggi. Menurut Hasan Langgulung pada masa pemerintahan Walid bin Abdul Malik didirikannya masjid di Damaskus yang merupakan universitas terbesar pada zaman itu. Dan didirikanlah juga masjid Az-Zaiunah di Tunisia yang dianggap sebagai universitas tertua di dunia yang didirikan oleh al Habhab pada tahun $114 \mathrm{H}$. Pada masa ini pula didirikan masjid Qairaqwan di Afrika Utara oleh Uqbah bin Nafi'. ${ }^{35}$ Metode pembelajaran ini diterapkan berdasarkan pemanfaatan seperti para putra raja di kirim ke badiyah untuk belajar bahasa arab murni dan mendalami puisi, untuk belajar membaca dan menulis, serta belajar berenang yang pada saat itu sangat dihargai terutama bagi mereka yang tingal di daera pantai Mediterania.

Adapun para lulusan pendidikan dapat diartikan sebagai mereka yang lulus dari jenjang pendidikan tertentu yang kemudian mendapatkan gelar tertentu dibidang keahliannya yang seanjutnya memiliki otoritas atau kepercayaan untuk mengajarkan ilmunya kepada yang lain. ${ }^{36}$ Para lulusan tersebut sesuai dengan jenjang dan jenis pendidikan yang mereka ikuti. Ada yang lulusan pendidikan istanah, badi'ah, perpustakaan, rumah sakit, serta ada pula yang lulusan dari pendidikan masjid dan kutab. Para lulusan tersebut adalah para tabi'in yang secara tidak langsung merupakan generasi kedua dari masa Rosulullah setelah sahabat. Diantara lulusannya adalah Imam Abu Hanifah, Imam Syafi'i, Ahmad bin Hambal, dan lain sebagainya.

\footnotetext{
${ }^{35}$ Ibid hlm 61

${ }^{36}$ Abudin Nata, Sejarab Pendidikan Islam..........hlm. 141-142
} 


\section{Kurikulum Pendidikan Islam Masa Abbasiyah (132-656 H / 750-1258 M)}

Semenjak lahir agama Islam maka lahir pula pendidikan agama Islam. Pembelajaran agama Islam terus berkembang dari masa Khalifaur Rasyidin, Daulah Ummayah sampai pada Daulah Abbasiyah yang pada saat itu ilmu pengetahuan sangat berkembang pesat. Sehingga kaum muslim baik tua, maupun muda saling berlomba-lomba untuk menuntut ilmu. Dari kecintaan akan ilmu inilah muncul bayak sekolah atau madrsaah pada saat itu. Sehingga sejarah mencatat pada masa inilah merupakan masa kejayaan dan keemasan Islam.

Pada masa ini yang mempunyai semangat mencari ilmu yang tinggil untuk meraih tujuan hidup manusia itu sendiri. Pada masa ini sudah mulai banyak cabang-cabang ilmu-ilmu yang dipelajaran yakni menekuni semua bidang keilmuan sehingga tujuan pendidikan pada masa Abbasiyah telah bermacammacam karena pengaruh masyarakat pada waktu itu diantaranya: Pertama, Tujuan keagamaan dan akhlak, tujuan ini merupakan tujuan yang paling mendasar dari ajara Islam karena manusia diciptakan untuk beribadah kepada Allah dan berperilaku dengan akhlak yang mulia. Kedua, Tujuan kemasyarakatan, tujuan ini untuk mendorong para pemuda untuk belajar dan menuntut ilmu pengetahua tentang kemasyrakatan supaya mampu untuk mengubah pola hidup masyarakat yang penuh kejahiliyaan menuju kehidupan yang bersinar dengan ilmu pengetahuan. Ketiga, Tujuan cinta akan ilmu pengetahuan, tujuan ini untuk menuntun umat Islam untuk terus menuntut ilmu dengan penuh kecintaan akan ilmu pengetahuan yang tidak mengelak apa yangakan diperoleh dari ilmu itu sendiri selain kedalaman ilmu pengetahuan. Keempat, Tujuan pendidikan kaum muslimin, yaitu tujuan kebendaan, tujuan ini supaya mereka yang menuntut ilmu mendapatkan kekuasaan, kekayaan dan supaya dapat berusahan dalam menjalani kehidupan didunia. ${ }^{37}$

Keempat tujuan pendidikan pada masa Abbasiyah merupakan salah satu bentuk dorongan dalam menggapai masa keemasan yang ditandai dengan kemajuan di berbagai bidang ilmu baik kebudayaan, ilmu pngetahuan, peradaban yang mengagungkan yang dapat dibuktikan baik melalui bukti sejarah maupun pengamatan empiris diberbagai belahan dunia. Contohnya di Irak, Mesir, Sepayol, India, dan sebagaian daerah Afrika utara.

Pada masa Abbasiyah sekolah-sekolah terdiri dari beberapa tingkat yaitu pendidikan rendah (dasar), pendidikan menengah, dan pendidikan tinggi.

${ }^{37}$ Mahmud Yunus Sejarah pendidikan Islam (Hida karya Agung, jakarta: 1990 M) hlm. $46-47$ 
Pendidikan rendah yang bertempat dikutab, selain di kuttab pendidikan rendah juga di selenggarakan di rumah, di istanah, di toko-toko. Materi yang diajarkan pada pendidikan rendah secara umum meliputi al-Qur'an dan menghafalnya, pokok-pokok agama Islam, menulis, kisah orang-orang besarIslam, membaca dan menghafal syair-syair, berhitung, dan pokok-pokok nahwu sharaf. ${ }^{38}$ Akan tetapi pada implementasinya berbeda-beda dari setiap wilayah seperti pendapat Mahmud Yunus bahwa di Maroko anak-anak hanya diajarkan Al -Qur'an saja, di Andalusia diajarkan Al-Qur'an dan menulis serta dicampur dengan syair, nahwu-sharaf, dan tulisan indah, di Tunisia dicampurkan pelajaran al-Qur'an hadits dan pokok-pokok agama Islam akan tetapi mengahfal Al-Qur'an sangat di pentingkan. Menurut keterangan Al Qobishy dalam Mahmud Yunus membagi mata pelajaran di Kuttab menjadi dua yaitu mata pelajaran wajib dan mata pelajaran tidak wajib (ikhtiariah). Mata pelajaran wajib berisi Al-Qur'an, shalat, do'a, sedikit ilmu nahwu sharaf, serta membaca dan menulis. Sedangkan mata pelajaran tidak wajib berisi berhitung, semua ilmu nahwu dan bahasa arab, syair, dan tarikh arab. ${ }^{39}$

Pendidikan tingkat menengah, yang bertempat di masjid, sanggar seni dan ilmu pengetahuan. Materi pendidikan menengah ini dari beberapa wilayah pada saat itu sangat berbeda-beda akan tetapi secara umum mengajarkan materi Al qur'an, bahasaarab dan sastra, fiqih, tafsir, hadist, balahgah, ilmu ilmu pasti, ilmu mantiq, falak, sejarah, ilmu ilmu alam, kedokteran, dan musik. Metode pembelajaran yang diterapkan pada pendidikan menengah dengan menggunakan ksikal dan halaqoh.

Pendidikan tingkat tinggi, Pada masa Bani Abbasiyah khususnya pendidikan tinggi pada setiap wilayah sama halnya dengan pendidikan rendah dan menengah yang mengajarkan materi yang berbeda, akan tetapi secara umum pendidikan tinggi di bagi menjadi dua jurusan yaitu jurusan ilmu-ilmu agama dan bahasa, dan jurusan ilmu ilmu hikmah (filsafat) dari dua istilah ini Ibnu Qoldun menamai dengan ilmu Naqliyah dan ilmu 'Aqliyah. Pendidikan ini dilaksanakan di masjid, madrasah, dan perpustakaan.

Penggolongan jenjang pendidikan ini seperti menurut Fazlur Rahman bahwa terdapat pendidikan dasar, pendidikan istana, pendidikan menengah, dan pendidikan tinggi. ${ }^{40}$ Tingkatan pendidikan ini berdasarkan pada golongan dan keadaan masyarakat yang secra langsung terjadi perubagan peradaban dan

\footnotetext{
${ }^{38} \mathrm{Ibid}, \mathrm{hlm} .48-49$

${ }^{39} \mathrm{Ibid}$ hlm. 49

${ }^{40}$ Fazlur RahmanIslamSecond Edition, University OfChicago Press Chicago And London,
} hlm. 180-182 
perubahan kemajuan ilmu pngetahuan yang sekaligus terjadi penekukan pada dua bidang ilmu yaitu ilmu modern dan ilmu agama.

Selain kuttab, masjid, badi'ah, istana, perpustakaan, dan rumah sakit terdapat lembaga pendidikan pada masa umayyah, pada masa abbasiyah berkembang pula lembaga pendidikan berupa toko buku, rumah para ulama, majlis al ilmu, sanggar kesusasteraan, observatorium, dan madrasah. ${ }^{41}$

Toko buku (a bawanit a warraqien), menggambarkan bahwa kota atau negara itu sedang mengalami kemajuan dalam bidang ilmu pengetahuan. Toko buku ini fungsi awalnya merupakan tempat untuk berjual beli, namun demikian menjadi tempat untuk pertunjukan peradaban dan kebudayaan serta kegiatan ilmu yang didatangi oleh para budayawan dan sastrawan dimana mereka mengambil bagian tempat berkumpul untuk melakukan kajian.

Rumah para ulama (manzil al ulama), pelaksanaan kegiatan belajar dirumah pernah terjadi pada awal permulaan Islam yaitu di rumah al Arqom (Dar Al Arqom). Pada masa Abbasiyah dianta rumah yang sering digunakan kegiatan ilmiah adalah rumah al rais Ibnu Sina, rumah Abu Sulaiman, rumah Imam Al Ghazali (504H), rumah Ya'qub bin Kalas wazir al aziz billah al fathimiy, rumah al sulfiy Ahmad bin Muhammad Abu Thahir (576H). Dirumahrumah inilah digunakan untuk kegiatan ilmiah, baik berdiskusi, tukar fikiran informasi, belajar membaca dan menulis, belajar pokok pokok keagamaan dan lain sebagainya. Pemilik rumah berperan sebagai ahlinya, dan pembelajaran dilakukan pada malam hari dikarenakan pada siang hari waktunya dihabiskan untuk bekerja.

Sanggar sastra (al Sholun al Adabiyah), sanggar ini mulai tumbuh ada masa bani ummayah dan berkembang pesat pada bani Abbasiyah, dan merupakan tindak lanjut perkembangan pada masa khalifah al Rasyidin. Didalam sanggar sastra ini terjadi upaya pengemabangan peradaban dan pengembangan ilmu pengetahuan. Dimana didalamnya terdapat kode etik tertentu yang tidak sembarang manusia bisa menempatinya. Sanggar sastra dibentuk dengan meniru kebudayaan asing yang diambil oleh khalifah Arab dari penguasa yang agung yang merupakan tanda kehormatan atas kekuasannya.

Madrasah, adalah lembaga pendidikan tingkat dasar dan menengah yang mengajarkan ilmu agama dan ilmu lainnya dengan menggunakan sistem klasikal. Sejarah mencatat madrasah mulai muncul pada masa Abbasiyah sebagai tindak lanjut dari pendidikan di masjid dan pendidikan yang lainnya.

Perpustakaan dan Observatorium, masa Abbasiyah mulai mendirikan perpustakaan, observatorium, tempat penelitian dan tempat kajian ilmiah

\footnotetext{
${ }^{41}$ Abuddin nata sejarah pendiidikan Islam......hlm. 152
} 
lainnya sebagai sarana mengembangakan ilmu pengetahuan. Tempat tempat ini dijadikan sebagai tempat belajara dalam arti yang luas, belajar bukan bertati menerima ilmu dari seorang guru akan tetapi belajar dengan cara berfokus pada keaktifan siswa.

Al Ribath, merupakan tempat untuk melakukan bimbingan, latihan, dan pengajaran bagi calon sufi. Dimana dalam ribat berlaku adanya komponen pembelajaran yang terkait degan pendidikan tasawuf, seperti komponen guru, syekh (guru besar), musrsyid (guru utama), mu’id (asisten guru), mufid (fasilitator). Komponen peserta didik dalam ribat dibagi sesuai dengan tingkatnya mulai ibtidaiyah, tsanawiyah dan aliyah, bagi peserta murid yang lulus akan diberi penghargaan berupa ijazah.

Az-Zawiah, tempat yang berada di samping masjid untk melakukan bimbingan wirid dan zikir untuk medapat kepuasan spiritual.

Ada pun materi yang diajarkan pada setiap jejang meliputi ilmu Naqliyah berisi tafsir alqur'an, hadits, fiqih dan usul fiqih, nahwu/sharaf, balaghah, dan sastra bahasa arab. Sedangkan materi yang diajarkan pada ilmu 'Aqliyah berisi mantik, ilmu alam dan kimia, musik, ilmu pasti, ilmu ukur, falak, ketuhanan, ilmu hewan, ilmu tumbuh tumbuhan, dan kedokteran. Mata pelajaran diatas belum menjadi spesialisasi diperguruan tinggi masa itu, akan tetapi spesialisasi ditentukan setelah tamat dari perguruan tinggi berdasarkan sesuai dengan minat masing-masing sesudah praktik mengajar. Spesialisasi ini tidak bisa dipahami seperti spesialisasi zaman sekarang.

Metode pembelajaran yang digunakan pada saat itu dengan halaqoh, diskusi kelompok, ceramah, dan hafalan untuk mengetahui hasil belajar peserta didik yaitu dengan cara menulis diktat yang kemudian dibacakan oleh pendidikan di hadapan para penulis diktat jika sudah selesai dengan memberikan catatan di pinggir diktat, kadang kadang juga guru memberikannya ijazah sebgai tanda sudah tamat dan berhak mengajarkannya kepada pelajar yang lain. ${ }^{42}$ Dari diktat diktat itu kemudian muncul kitab kitab tulis tangan yang menjadi kitab termasyhur seperti diktat al Qoli (amali al qoli), diktat al murtadli, (amali al murtadli), dan diktat al hajib (amali al hajib). Pada masa Abbasiyah dikenal adanya tradisi ilmiah yang baisa dilakukan oleh para ilmuan dan para ahli yang lainya dalam mengembangan ilmu pengetahuan melalui tradisi ilmiah tersebut. Tradisi ilmiah ini meliputi Muzakarah (tukar-menukar informasi), Munazarab (berdebat), rihlah ilmiah, penerjemahan, mengoleksi buku dan mendirikan perpustakaan, mendirikan lembaga pendidikan, melakukan penelitian ilmiah, menulis buku, dan memberi wakaf.

${ }^{42} \mathrm{Ibid}$, hlm. 60 
Beberapa perguruan tinggi pada masa Abbasiyah Bitul Hikmah di Bagdad didirikan oleh Khalifah Harun al Rosyid (786-809M/170-193H) dan diteruskan khalifah al Makmun (198-218H/813-833m). ${ }^{43}$ Pada baitul hikmah ini banyak terjadi proses penerjemahan buku buku Yunani ke dalam bahasa arab. Baitul hikmah dapat dikatakan fakultas ilmu penegtahuan, dan Baitul Hikmah pada masa al Makmun adalah masa keemsannya, dimana baitul hikmah ini satusatuny univesitas yang memiliki guru-guru besar yang luar biasa, memiliki perpustakaan umum yang berharga, dan alat peneropong bintang terbaik pada zaman pertengahan itu.

Pada dinasti Abbasiyah yang dikenal dengan masa keemasan umat Islam pada semua ranah bidang kehidupan meliputi administrative pemerintah dengan biro bironya, system organisasi militer, administrasi wilayah pemerintah, pertania, perdagangan, industry, pertanian, perdagangan, industry, Islamisasi pemerintah, kajian dalam bidang kedokteran, astronomi, matematika, geografi, histografi, filsafat Islam, teologi, hokum, etikaIslam, satra, seni, penerjemah, pendidikan, kesenian, perguruan tinggi, perpustakaan, toko buku, media tulis, senirupa, senimusik, dan arsitek ${ }^{44}$.

Kemajuan disemua bidang aspek kehidupan diiringi dengan kemajuan dalam bidang pendidikan yang mampu mencetak generasi - generasi dan ulama-ulama, serta ilmuan-ilmuan terkemuka di dunia sampai zaman sekarang.

\section{Refleksi Kurikulum Pendidikan Islam Klasik dalam Konsep Pendidikan Islam Masa Kini}

Kurikulum merupakan sebuah istilah yang sangat penting bagi lembga pendidikan baik lembaga pendidikan Islam maupun lembaga pendidikan umum. Kurikulum pendidikan mencakup segala aspek yang berkaitan dengan proses pembelajaran. Akan tetapi kajian kurkulum lebih difokuskan pada empat komponen yaitu sabjek, tujuan, metode, dan hasil belajar.

Kurikulum pendidikan Islam klasik bisa dikatakan sebuah permulaan sistem pendidikan Islam yang masih sangat sederhana akan tetapi dari kesederhanaan itulh mampu mencetak para tokoh, ulama, ilmuan yang snagat lauarbiasa. Pendidikan yang diterapkan Rosulullah pada masanya beliau merupakan cikal bakal proses pendidikan Islam yang mampu mnginspirasi para sahabat, tabin, tabi'in tabi'in sampai pada saat ini.

Dari tema Kurikulum Pendidikan Islam khususnya dalam pembahasan ini adalah kurikulum pendidikan Islam masa klasik dapat membedrikan gambaran

\footnotetext{
${ }^{43} \mathrm{Ibid}$, hlm 65

${ }^{44}$ Dedi Supriyadi, Sejarah Peradaban Islam, (Pustaka Stia: Bandung, 2008), hlm. 130-136
} 
baru bahwa pendidikan Islam yang diterapakan di Indonesia ini merupakan perkembangan sistem pendidikan masa klasik. Dimana dari makalah makalah ini bisa mengetahu komponen kurikulum yang paling pokok yang harus diperhataikan dalam menyamapaikan isi pendidikan kepada peserta didik.

Dari sisi kelembagaan pendidikan Islam dapat diketahui bahwa lembaga pendidikan Islam terus erkembnag dari mas ke masa yang dimulai lembaga pendidikan pasda masa Rosulullah rumah yang disebut Dar Al Arqom kemudian pada masa keemasan mampu sampai pada lembaga pendidikan Tinggi yang di awali Pendidikan Tinggi Zaituna.

Kemudian jika dilihat dari komponen kurikulum itu sendiri yang terdiri dari:

Tujuan pendidikan, jika ditelaah tujuan pendidikan ini sangat penting ditetapkan karena jika tanpa tujuan pendidikan yang jelas maka tidak akan adanya proses pendidikan yang baik. Seperti pada masa Rosulullah tujuan pendidikan yang paling pokok adalah membentuk manusia yang bertakwa dan berakhlakul karima (menurnikan Tauhid) dengan melihat kondisi masyarakat pada waktu itu masih awal Islam. Sampai pada masa Abbasiyah tujuan pendidikan yang sudah sangat kompleks. Jika ditarik pada dunia pendidikan modern seperti saat ini maka hendaknya pendididkan jika memperhatikan kondisi lingkungan yang semakin sangat kompleks.

Materi pendidikan, materi pendidikanini muncul setelah adanya tujuan yang jelas. Materi pendidikan juga semakin berkembangan dengan kondisi masing-masing masyakat. Atau kondisi peserta didik yang akan menerima materi pendidikan itu sendiri. Materi pendidikan diterapkan mulai dari materi yang sangat sederhana sampai pada materi yang sangat kompleks dengan memeperhatikan perkembangan psikologi dan kognitif dari peserta didik, mislanya dari materi Al-Qur'an terus berkembang sampai pada materi filsafat.

Matode pembelajaran, metode juga berperan penting dalam melaksanakan tugas pendidikan untuk mencapai tujuan pembelajaran secara sempurna dengan hasil yang maksimal. Metode yang ditekan pada materi pendidikan Islam yang diajarkan oleh Rosulullah adalah metode keteladanan dan pembiasaan terhadap peserta didik. Dengan memperhatikan peserta didik dalam menerima materi ajar.

Hasil pembelajaran, merupakan keluaran dari proses pendidikan, dalam hal ini hasil pembelajaran tidak semata-mata sebuah nilai kan tetapi kompetensi yang dikuasa peserta didik yang mampu diterapakan dalam kehidupan seharihari baik untuk pribadi maupun sesama makhluk Allah. Hasil pembelajaran juga semata mata pada ijazah yang diperoleh akan tetapi penguasaan kompetensi belajaar yang diperoleh. 
Dengan demikian dapat diambil pelajaran sebagai perubahan sistem pembelajaran yang diterapkan di masa sekarang dan dari tema ini mendapatkan gambaran untuk perubahaan proses pembelajaran yang akan diterapkan dilembaga pendidikan.

Perlunya perubahan paradigma pendidikan Islam di tingkat SD, SMP, SMA, Perlunya evaluasi penetapan tujuan pembelajaran yang sesuai dengan kebutuhan peserta didik, Perlunya evaluasi materi-materi yang relevan dengan tujuan dan kebutuhan peserta didik dalam kehidupan sehari-hari, Perlunya pemilihan metode pembelajara sesuai dengan tujuan, mteri dan tingakat perkembangan peserta didik, Perlunya pelatihan atau training bagi para guru dalam memahami pendidikan Islam, Perlunya evaluasi penetaan hasil belajaar yang tidak menekan kan pada aspek kognitif saja.

\section{KESIMPULAN}

Dari pemaparan tentang kurikulum pendidikan Islam pada masa klasik di atas dapat disimpulkan sebagai berikut:

\section{Masa Rosulullah (12SH-11SH/611-632M) Mekkab}

Tujuan pendidikan untuk membentuk manusia yang beriman dan bertakwa, dan berakhlak mulia sebagai landasan bagi mereka dalam menjalani kehidupan sosial. Adapun tujuan pendidikan secara khusus adalah bertujuan agar manusia dapat bertingkah laku mulia dan menjauhi tingkah laku jahat. Materi yang di ajarkan adalah Aqidah (Keimanan), akhlak dan Al-Qur'an. Metode pembelajaran yang digunakan adalah pidato, ceramah, keteladanan, pembiasaan, dan hafalan. Hasil pembelajaran, mampu membaca dan menghafal Al-Qur'an serta dapat menjalankan kehidupan sesuai dengan ajaran Islam. Lembaga pendidikan yang digunakan berupa Rumah (Dar Al Arqom), Kuttab

\section{Madinab}

Tujuan pembinaan pendidikan sosial dan politkagar dijiwai dengan tauhid, sehingga akhirnya tingkah laku sosial politiknya merupakan cermin dan pantulan sinar tauhid yang berdasarkan wahyu yang diturunkan kepada Nabi. Materi yang diajarkan tentang pendidikan keagamaan, pendidikan akhlak, kesehatan jasmani dan pengetahuan yang berkaiatan dengan kemasyarakatan. Metode pembelajaran yang digunakan adalah pidato, ceramah, keteladanan, pembiasaan, membaca, menulis, praktik, dan hafalan. Hasil pembelajaran, keberhasilan sosial politik masyarakat Madinah yang mampu membawa kaum 
muslim menuju kesejahteraan masyarakat dan peluasan wilyah kekuasaan Islam dengan sinar ketahidan yang kuat. Lembaga pendidikan yang digunakan berupa rumah, Kuttab, dan Masjid.

\section{Kholifah Al Rosyidin (623-661M/12-41H)}

Tujuan pendidikan untuk melahirkan umat yang tulus dan kukuhterhadap pelaksanaan ajaran Islam sebagaimana yang dijarkan oleh Nabi Muhammad SAW. Materi yang diajarkan adalah al Qur'an, akidah ibadah, syariah dan akhlak, pelajaran berenang, menungggang kuda, pepatah-pepatah dan syair-syair yang baik, dan Al-Qur'an dan tafsirnya, hadits dan pengumpulanya, dan fiqih (tasyri'). Metode pembelajaran yang digunakan adalah sorogan dan halaqoh, ceramah dan hafalan. Hasil pembelajaran yang diharapkan adalah kemampuan seseorang dalam menguasai bahan ajar dilihat dari kemampuannya untuk mengemukakan, mengajarkan, dan mengamalkan ajaran Islam. Lembaga yang digunakan beruapa kuttab, masjid, al Suffah, dan rumah.

\section{Daulah Umayyah (41-132H/661-750M)}

Tujuan pendidikan untuk menghasilkan sumberdaya manusia yang unggul secara seimbang dalam ilmu agama dan ilmu umum serta mampu menerapkan bagi kemajuan wilayah Islam. Materi yang diajarkan berupa ilmu-ilmu agama, ilmu sejarah dan geografi, ilmu filsafat, dan ilmu pengetahuan bidang bahasa. Metode pembelajaran yang digunakan adalah hafalan, ceramah, sorogan atau mandiri dan halaqoh. Hasil pembelajaran untuk mendapatkan gelar tertentu dibidang keahliannya yang seanjutnya memiliki otoritas atau kepercayaan untuk mengajarkan ilmunya kepada yang lain. Lembaga pendidikan yang digunakan berupa rumah, kuttab, masjid, istanah, badiah, perpustakaan, Al Bima ristan.

\section{Daulah Abbasiyah (132-565H/750-1258M)}

Pada Daulah Abbasiyah ada beberapa tujuan pendidikan yaitu: tujuan keagamaan dan akhlak, tujuan kemasyarakatan, tujuan cinta akan ilmu pengetahuan, tujuan pendidikan kaum muslimin. Materi yang diajarkan terdiri dari pendidikan rendah: al-Qur'an, pokok-pokok agama Islam, sejarah Islam, bahasa dan sastra, berhitung, dan pokok-pokok nahwu sharaf, fiqih, tafsir, hadist, balahgah, ilmu ilmu pasti, ilmu mantiq, falak, sejarah, ilmu ilmu alam, kedokteran, dan musik. Metode pembelajaran yang digunakan berupa ceramah, menulis, membaca, hafalan, berhitung, keteladanan, klasikal, halaqoh, berdebat, dan tukar menukar informasi. Hasil pembelajaran diharapkan terdapat banyak ulama yang mahir dalam banyak bidang, atau mampu menguasai ilmu 
umum dan ilmu agama seperti Ibnu Sina, Ibnu Rusy, Al Ghazali, dll. Lembaga pendidikan yang digunakan berupa rumah, kuttab, masjid, perpustakaan, istanah, Al Bimaristan, toko buku, rumah para ulama, sanggar sastra, madrsah, Al Ribath, perpustakaan dan observatorium, dan Az Zawiyah.

\section{DAFTAR PUSTAKA}

Abudin Nata, 1997, Filsafat Pendidikan Islam 1, Logos, Jakarta

Abudin Nata, 2011, Sejarab Pendidikan Islam, Kencana Predana Media Group, Jakarta.

Ahmad Tafsir, 2004, Cakrawala Pemikran Pendidikan Islam, Bandung, Mimbar Pustaka

Arifudin Arif, 2008, Pengantar Ilmu Pendidikan Islam cet. 1, Kultura GP Press Groupipta, Jakarta

Dedi Supriyadi, 2008, Sejarah Peradaban Islam, Pustaka Stia : Bandung, Jakarta

Dakir, 2004, perencanaan dan pengembangan Kurikulum, cet.1 Rineka Cipta

Fazlur RahmanIslam Second Edition, University Of Chicago Press Chicago And London

Haidar Putra Daulay dan Nurgaya Pasa, 2013, Penididkan Islam Dlam Lintasan Sjarab Kajian dari zaman pertumbuhan sampai kebangkitan, Kencana Predana Media Group, Jakarta

Mahmud Yunus, 1990, Sejarab pendidikan Islam Hida karya Agung, Jakarta

Pilip K Hitty , 2014, History Of the Arabs. Terj. Jakarta, Serambi Ilmu Semesta Samsul Nizar, 2014, Sejarab Pendidikan IslamMenelusuri jejak sejarah Pendidikan Islam, Era Rosulullah sampai Indonesia, Kencana Predana Media Group, Jakarta

Suwendi, 2004, Sejarah Dan Pemikiran Islam, Raja grafindo Persada, Jakarta, Zuhairini, dkk, 1985,Sejarah Pendidikan Islam cet. II Jakarta, PTAIN IAIN Jakarta

Zuhairii, dkk, 2004, Sejarah Pendidikan Islam, Bumi Aksara, Jakarta 